\title{
Kitap Değerlendirme
}

\section{BILGE KAĞAN KÖL TIGIN VE BILGE TONYUKUK}

\section{Prof. Dr. İlhami DURMUŞ}

DURMUŞ, İlhami, Bilge Kağan Köl Tigin ve Bilgi Tonyukuk, Geniş̧letilmiş 3. Baskı, Akçağ Yayınları, Ankara 2017, 203 sayfa.

\section{Sinan TARIFCI*}

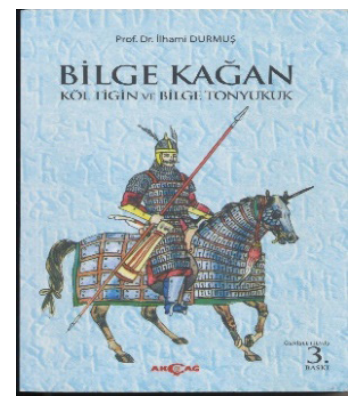

Tanıtımını yapmaya gayret edeceğimiz eser, ilk defa 2009 yılında Maya Akademi Yayınları tarafından basılmıştır. 2012 yılında Akçağ Yayınları tarafından ikinci baskısı yapılan eser, nihayet 2017 yılında aynı yayınevi tarafından üçüncü kez basılmıştır. Her yeni baskıda içerik bakımından daha da kıymetlendirilen eserin biz burada genişletilmiş üçüncü baskısını esas alacağız. Yazar, eserde ele aldığı konulara dair şimdiye kadar yaptı̆̆ 1 araştırmalarının neticelerini muntazam bir tasnif çerçevesinde toplu bir şekilde vermektedir. Eser ifade, dil ve üslup bakımından sade ve anlaşılırdır. Bu özelliği ile yalnız tarih araştırmacılarının ve yazarlarının değil, tarih meraklılarının ve okuyucularının da ilgisine sunulmaktadır.

Eser; L̇çindekiler (s. 5-7), Önsöz (s. 9-10), Giriş (s. 11-12), Sonuç (s. 151153), Ekler (s. 156-193) ve Kaynaklar (s. 195-203) kısımlarından başka, başlica şu üç bölümden oluşmaktadır: I. Bölüm: Bilge Kağan, Köl Tigin, Bilge Tonyukuk ve Anıtlıklarl (s. 13-74), II. Bölüm: Anıtlıkların Yazılı Belgeleri, Belgeler Işığında Türk Adı, Türk Milli ve Manevi Unsurları (s. 75-114), III. Bölüm: Anıtlıkların Kalıntı, Buluntu ve Belgelerine Göre Türk Kültür Unsurları (s. 115-153).

Arş. Gör., Gazi Üniversitesi Sosyal Bilimler Enstitüsü, sinantar@hotmail.com 
Yazar, eserinin Önsözünde, tarih öncesi devirlerden başlayan Türk tarihinin, günümüze yaklaştıkça belgelerinin ve dolayısıyla bilgilerin arttığından bahisle; Gök Türk döneminin, Türk tarihinin bütünlüğü içerisinde belge ve bilgi bakımından müstesna bir yerinin olduğunu ifade etmektedir. Gök Türk dönemi içinde ise Bilge Kağan döneminin özel bir yeri olduğunu eklemektedir. Zira Gök Türk dönemi belgelerinin en kayda değerlerinin Bilge Kağan dönemi yazıtları ile anıtlıkların kalıntı ve buluntuları olduğunu vurgulayan yazar, böylece eserinin kapsamını ve temel kaynaklarını da bildirmektedir (s. 9-10).

Eserin Giriş kısmında Türklerin konar-göçer hayatının izlerinin bozkırlarda aranması gerektiğinden hareketle, Türk tarih ve kültürü açısından özel bir yeri bulunan ve Bilge Kağan ve Köl Tigin Anıtlıklarına da ev sahipliği yapan Moğolistan bozkırları hakkında kısa bir bilgi verilmektedir (s. 11). Devamında ise anıtlıkların keşfi, bilim çevrelerince tanınması ve Gök Türk harflerinin çözülmesi gibi konular özetlenmektedir (s. 12).

Yazar, Bilge Kağan, Köl Tigin, Bilge Tonyukuk ve Anıtlıları adlı I. bölümün (s. 13-74) ilk kısmında (s. 13-53), Bilge Kağan, Köl Tigin ve Bilge Tonyukuk'un adlarını, yetiştikleri çevreleri, kişilikleri ve siyasi ve askeri faaliyetlerini ele almaktadır. Dönemin en tanınmış şahsiyeti olarak nitelediği Bilge Kağan'ı ilk olarak ele alan yazar, söz konusu şahsiyetin "Bilge" ve "Kağan" ad ve unvanlarının Türkçede, Çincede ve Türk kültür çevresinde kullanışlarından başlamak üzere, Gök Türk kültür çevresinde kullanılan başka adlar ve anlamları hakkında bilgiler vermektedir (s. 13-16). Yazıtlarda geçen ifadelerden hareket eden yazar; ülke, halk ve teşkilât üçgeninde Bilge Kağan'ın yetiştiği çevreyi tasvir etmektedir. Özellikle yaylak ve kışlak arasında konar-göçer bir hayat tarzına sahip olan Türklerin, bu hayat tarzının icabı olarak sahip olduğu meziyetlere dikkat çeker (s. 16-21). Bilge Kağan'ın yaptığı işler bağlamında onun karakterini tahlile girişen yazar, kağanın kişiliğine yansıyan şu niteliklerini tespit etmiştir: Belirgin millet ve ülke sevgisi, istiklâle düşkünlük, başarılarının temelinde Tanrı'nın bulunduğu inançlı bir kişilik, tarih şuuru, töreye bağlılık ve adalet (s. 21-31). Bilge Kağan'ın "Şad” olmasından başlamak üzere ölümüne kadar olan siyasi ve askeri faaliyetleri de yazıtlarda anlatıldığı şekliyle özetlenmiştir (s. 31-34). Köl Tigin faslında yazar, aynı şekilde öncelikle "Köl” ve "Tigin" ad ve unvanlarının anlamlarını açıklamaktadır. Ayrıca, Köl Tigin'in kullanmış olduğu başka ad ve unvanlardan da bahsetmektedir (s. 34-37). Ağabeyi Bilge Kağan'ın yetiştiği çevrenin Köl Tigin'in de hayatını sürdürdüğü çevre olduğundan bahseden yazar (s. 38), Köl Tigin'in kararlılık, cesaret, kahramanlık, dürüstlük, sadakat gibi kişilik özellikleri üzerinde durur (s. 38-40). Delikanlılık çağına girdikten sonra hayatı hep mücadele içinde geçen Köl Tigin'in kahramanlıklarından söz edilmiştir (s. 40-43). Yazar, Bilge Tonyukuk faslında ise "Tonyukuk" başta olmak üzere onun aldığı ve kullandığı diğer ad ve unvanların anlamlarını ve okunuş farklılıklarını açıklamaktadır (s. 43-47). Devamında, Tonyukuk'un Çin kültür çevresinde yetişmesine rağmen kültür çevresini değiştirerek, Türklerin 
bağımsız olarak varlığını sürdürdüğü bozkır çevresine geçtiğini belirten (s. 48) yazar, onun şu kişilik özelliklerine dikkat çeker: Uyanıklık, kurnazlık, zekilik, kahramanlık, bilgelik ve iyi bir stratejist (s. 49-50). Birinci bölümün ilk kısmı, Bilge Tonyukuk'un Türk devletinin gelişip büyümesinde oynadığı rollerin kısaca açıklanmasıyla sona erer (s. 50-53).

Birinci bölümün ikinci kısmında (s. 54-74) Bilge Kağan, Köl Tigin ve Bilge Tonyukuk Anıtlıkları arkeolojik yönleriyle incelenmiştir. İlk olarak anıtlıklarda yer alan bengü taşlar, insan heykelleri, kaplumbağa heykeli, koç heykelleri, aslan heykelleri, sunak taşları gibi yapılar hakkında bilgi verilerek; anıtlıklar tasvir edilmiştir (s. 54-68). Devamında ise anıtlıkların planları, ölçüleri, kalıntı ve buluntuları, iç ve dış düzenlemeleri bakımından benzerlikleri karşılaştırıldıktan (s. 68-70) sonra kullanılan taş, toprak ve ahşap malzemeler konu edilerek, bu malzemelerin nerelerden getirildiği, nasıl taşındığı ve anıtlıkların nasıl yapıldığı gibi sorulara cevap aranmıştır (s. 70-74).

Eserin II. bölümü (s. 75-114) Anıtlıkların Yazılı Belgeleri, Belgeler ışı̆ı̆nda Türk Adı, Türk Milli ve Manevi Unsurları adını taşımaktadır. Yazar bölümün başında, yazının toplumların tarihlerinin aydınlatılmasında oynadığı role dikkat çekerek, yazının icadı, atlı-göçebe toplulukların yazıyla tanışmaları ile yazının kullanımına temel oluşturan unsurları ele almıştır (s. 75-80). Özellikle atlıgöçebelerin yazı türü olan runik (oyma) yazıların kökeni meselesine değinen yazar, bu konuda bilim adamlarının ileri sürdükleri 7 farklı görüşe yer vererek, bu görüşlerin orijinalliğini ve kabul edilebilir olup olmadıklarını tartışmıştır (s. 80-84). Öte yandan, Türkçe konuşan toplulukların yazı sistemlerini ve en eski yazı örneklerini değerlendirmiştir (s. 84-89). Bölümün ikinci kısmı Türk adının ortaya çıkışı, anlamı ve yayılışı meselelerine ayrılmıştır. Bu itibarla yazar, Türk adının geçtiği kaynakları, Türk adının çeşitli anlamlarını, yazıtlarda geçen Türk adının ifade ettiği manaları ve Türk adının geniş coğrafyalara yayılarak daha da yaygın olarak kullanılmaya başlandığını açıklamaktadır (s. 89-98). Bölümün sonunda ise millet sevgisi, istiklâl anlayışı, ülke sevgisi, töreye bağlılık, tarih şuuru ve Tanrı'ya bağlılık temelinde Türk milli ve manevi unsuları ortaya konulmaktadır (s. 99-114).

Eserin III. bölümü (s. 115-150) Anitlkların Kalıntı, Buluntu ve Belgelerine Göre Türk Kültür Unsurları başlığı altında tertip edilmiştir. İlk olarak Türklerin görünüşü ve giyimi hususunda ipuçları veren insan heykel, tasvir ve sembolleri ele alınıp; heykeller, taşbabalar ve sade balballar hakkında bilgi verilmiştir. (s. 115-118). İkinci olarak anıtlıkların önemli unsurlarından olan Bilge Kağan, Köl Tigin ve Bilge Tonyukuk bengü taşları, küp şeklindeki sunak taşları ve yoğ törenlerinde adanan hatıra taşlarından söz edilmiştir (s. 119122). Bölümün üçüncü kısmında at, koyun, yaban sığırı, kurt, kartal, arslan, geyik ve kaplumbağa gibi hayvanların Türklerin sosyal, siyasi, iktisadi, dini ve askeri hayatında muhtelif bakımlardan önemli yerlere sahip olduğu ifade

Akademik Bakış 305 Cilt 11 Sayı 21 Kış 2017 
edildikten sonra, söz konusu hayvanların anıtlıklardaki heykelleri, tasvirleri ve sembollerine dikkat çekilmiştir (s. 123-140). Devamında bengü taşlar, hatıra taşları, taşbabalar üzerine kazınan damgalar ve hayvanlar üzerine vurulan damgalar ile bu damgaların Türk kültür çevresindeki benzerlikleri ve kültürel süreklilik içerisindeki yeri gösterilmiştir (s. 140-143). Yazar, son olarak ise ok, yay, kılıç, kama, mızrak, zırh, miğfer ve kalkan gibi eski Türk savaş araç ve gereçleri hakkında bilgi vermiştir (s. 144-150).

Eserin Sonuç (s. 151-153) faslında anıtlıkların Türk tarihi, kültürü ve arkeolojisi açısından önemi vurgulanmıştır. Sonuçtan sonra geniş bir Ekler (156-193) bölümü bulunmaktadır. Bu bölümde Köl Tigin Anıtlığına ait 2 çizim; Göktürk harfleri ve karşılıkları, Köl Tigin Yazıtının farklı cephelerinden yazı Örnekleri, Oğuz boyları ve damgaları vs. den oluşan 10 belge; Anıtlıklara ve bölgede yapılan arkeolojik çalışmalar neticesinde ortaya çıkarılan kalıntı ve buluntulara ait 30 resim yer almaktadır. Eser, yerli ve yabancı yazarlara ait kaynak neşirleri ve tetkik eserlerden müteşekkil Kaynaklar (s. 195-203) listesiyle son bulmaktadir.

Kitabın son birkaç sayfasında ise yazarın aynı yayınevinden (Akçağ) çıkan Türk Kültürüne Giriş, Türk Tarihinin Öncüleri, İskitler ve Sarmatlar adlı kitaplarının ön kapak resimleri ve tanıtım bültenleri bulunmaktadır. Yayınevi tarafından tanıtım amaçlı olarak yer verildiği anlaşılan bu sayfalarda yazarın Iskitler ve Sarmatlar adlı kitaplarının kapak resimlerine bakıldığında, her ne kadar kapak görseli her baskıda aynı kalsa da, eserin kaçıncı baskısı olduğuna dair bilgi veren kısımda, önceki baskıların adı geçtiği görülmektedir. Yani, 2017 yılı içerisinde 6. baskısını yapmış olan İskitler (236 sayfa) adlı kitap, 4. baskı olarak; yine aynı yıl içerisinde 4. baskısını yapmış olan Sarmatlar (160 sayfa) adlı kitap ise 3. baskı olarak görülmektedir. Elimizdeki bu Bilge Kağan Köl Tigin ve Bilge Tonyukuk adlı kitabın, adı geçen diğer kitapların son baskılarından kısa bir süre önce matbaaya girdiği anlaşıldığından, bu durum teknik olarak mazur görülebilir. Biz yazarın diğer kitaplarını da zikretmek gereği duyduğumuzdan dolayı bu durumu bir vesile bildik. Yazarın Türk Tarihinin Öncüleri (168 sayfa) ve Türk Kültürüne Giriş (541 sayfa) adlı kitaplarının ise ilkinin 2013 yılında, ikincisi ise 2016 yılında neşredildiğini de ekleyelim.

Prof. Dr. İlhami Durmuş'un tanıtımını yapmaya çalıştığımız Bilge Kağan Köl Tigin ve Bilge Tonyukuk adlı kitabının ihtiva ettiği konulara dair kaleme aldığı muhtelif makaleler ve raporlar ile sunduğu tebliğleri de bulunmaktadır. Yazarın bu çalışmalarının bir kısmının da kısa bir listesini vermenin ilgililere faydalı olacağını düşünüyoruz: "Türklerin Kullandığı Armalar", Milli Folklor, S. 21, 1994, s. 40-44; "Eski Türklerde Yazı", Milli Folklor, S. 22, 1994, s. 37-39; "Bozkır Kültürünün Oluşumu ve Gelişiminde At", Gazi Üniversitesi Fen-Edebiyat Fakültesi Sosyal Bilimler Dergisi, S. 2, 1997, s. 13-19; "Moğolistan'daki Türk Anıtları Projesi", Avrasya Etüdleri, S. 17, 2000, s. 133-142; "Köl Tigin Külliyesi Kalıntıları 
ve Türk Kültür Çevresindeki Yeri", Türk Dili Araştırmaları Yillı̆ı-Belleten, Ankara 2001, s. 183-190; “Bilge Kağan ve Köl Tigin Külliyelerinin Türk Tarih ve Kültürü Açısından Değeri", Orhun Sempozyumu, 11 Mart 2002, Ankara, Sempozyum Bildirileri s. 1-10; "Eski Türklerde Askeri Kültür", Silahl Kuvvetler Dergisi, S. 385, 2005, s. 4-25; "Arkeolojik Kalıntı ve Buluntulara Göre Köl Tigin ve Bilge Kağan Külliyeleri”, Bilim ve Ütopya, S. 140, 2006, s. 31-35; "Arkeolojik Kalıntı, Buluntu ve Yazılı Belgelere Göre Köl Tigin-Bilge Kağan Anıtlıkları ve Bu Anıtlıklardaki Türk Kültür Unsurları", Gazi Türkiyat Türklük Bilimi Araştırmaları Dergisi, S. 1, 2007, s. 35-57; "Türk Kültür Çevresinde Renkler", Folklor/Edebiyat, S. 50, 2007, s. $163-$ 172; "Bozkır Kültür Çevresi Türk Tarihi Araştırmaları ve Kronoloji”, Gazi Türkiyat Türklük Bilimi Araştırmaları Dergisi, S. 5, 2009, s. 129-141; “Türk Kültür Çevresinde Kültür Adlandırmaları", Gazi Akademik Bakış, S. 15, 2014, s. 269-298; "Türk Adının Ortaya Çıkışı, Anlamı ve Yayılışı”, Gazi Akademik Bakış, S. 20, 2017, s. 37-47.

Sonuç olarak, Prof. Dr. İlhami Durmuş'un otuz yılı aşan eski bozkır kavimlerinin tarihi ve kültürü araştırmalarından edindiği bilgi ve tecrübeyle, genişleterek neşrettiği bu eser, Türk tarihi ve kültürü araştırmalarına önemli bir katkı sağlayacağı gibi; tarih ve kültür meraklıları için de bir başvuru kitabı olacaktır. Yazarın deyimiyle "millet sevgisiyle devlet yönetmiş Bilge Kağan, kahramanlığıyla kendini kanıtlamış Köl Tigin ve devlet adamlığıyla ün kazanmış Bilge Tonyukuk" devirlerinin siyasi ve kültürel gelişmelerini ele alan eser, aynı zamanda Türk siyasi ve kültür tarihine de bir giriş mahiyetini haizdir. Yazarın eserlerini tanıtmaya ve değerlendirmeye devam edeceğiz. 